\title{
Improved Epilepsy and Speech Outcomes with Human Embryonic Stem Cell Therapy in Children with Cerebral Palsy

\section{Abstract}

Introduction: Cerebral Palsy (CP) is a group of permanent neurological disorders which is prevalent in children of neonatal age and is often associated with epilepsy and speech disorders. The various conventional treatments and therapies available so far are unable to treat these comorbidities. In this study, we aimed to evaluate 101 patients with CP having speech disorders and epilepsy. The patients were treated using human embryonic stem cells (hESC) therapy and assessed by Gross Motor Function Classification System-Expanded and Revised (GMFCS-E \& R) score.

Materials and Methods: Patients were given hESCs via different routes of administration for duration of 8 weeks and evaluated before and after the treatment on the basis of their levels of gross and motor function of improvement, i.e., frequency of the epileptic attacks and ability to speak. Single photon emission computed tomography (SPECT) scan investigations were also performed to support the studies.

Results: There was an improvement in $96.61 \%$ of the epileptic patients and $91.39 \%$ of the patients with speech disorder. Of 59 patients affected with epilepsy, 18 patients had shown complete disappearance of epileptic episodes; and of 93 patients affected with speech, 27 patients became completely verbal.

Conclusion: Hence, hESC therapy might be beneficial in patients with CP having epilepsy and speech disorders.

\section{Geeta Shroff'1.}

1 Director, Nutech Mediworld, New Delhi, India.

\section{Contact information:}

\section{Geeta Shroff.}

Address: Nutech Mediworld, H-8, Green Park Extension, New Delhi-110016.

Tel: +911126180039

Fax: +91 1126560089

झ geetashroff@hotmail.com 


\section{Introduction}

Cerebral Palsy (CP) is one of the most common lifelong disorders that appear in infancy or early childhood. The prevalence estimates for worldwide population-based studies for CP ranges from 1.5 to 4 per 1,000 live births or children of a defined age range. Latest survey conducted by CDC's Autism and Developmental Disabilities Monitoring (ADDM) Network reports that about 1 in 323 children is identified with CP $[1,2]$.

CP can be congenital; caused due to preterm delivery, multiple gestations, and other pregnancy complications, genetic abnormalities, maternal infections/fevers, or fetal injury or it can be acquired, where brain infections such as bacterial meningitis or viral encephalitis, problems with blood flow to the brain, or head injury from a motor vehicle accident, a fall, or child abuse can lead to cause CP [3-5].

It is associated with major disabilities of the body such as disturbances of sensation, perception, cognition, communication, behavior, epilepsy, and secondary musculoskeletal problems $[6,7]$. Co-morbidities in CP affect the overall health and quality of life. It is observed that the patients with $\mathrm{CP}$ have most common symptoms of speech motor disorder such as dysarthria and neurological disorder such as epilepsy [8-11].

Most of the symptoms of CP do not have specific and curative treatments. Majority of the optimal therapies designed so far do not yield much effective results. The reasons behind the failures are usually variations in quality of treatment required and different symptoms of different age groups [12]. Besides available conventional treatments, various stem cell therapies like umbilical cord blood stem cells (UCBSCS), bone marrow stem cells, induced pluripotent stem cells (iPSCs) have also been studied for CP patients. These cells have high potential of pluripotency and can differentiate into various other tissues and can also restore neuronal damage. Nevertheless, stem cells have been used in various neurological disorders but still future trials are needed to confirm their long-term efficacy [12-15]. Therefore, there is a need to develop clinically significant techniques to treat $\mathrm{CP}$ which can target specific problem.

We have previously demonstrated the safety and efficacy of human embryonic stem cell (hESC) therapy in our patients with $\mathrm{CP}$, and there was a remarkable clinical improvement observed in them [16]. The present study is a subgroup analysis of the patients with CP who had epilepsy and speech disorders before initiating hESC therapy.

\section{Materials and Methods}

\section{Ethical statement}

The study protocol was approved by the Independent Institutional Ethics Committee. The institutional committee for stem cell research and therapy of Nutech Mediworld reported the clinical study to National Apex Body. The study was conducted in accordance to the Declaration of Helsinki.

\section{Study characteristics and design}

This study was a retrospective analysis for epilepsy and speech outcomes of a total cohort of $101 \mathrm{CP}$ patients who were treated with hESC therapy. The study was conducted from 01 October 2007 to 31 July 2013 at Nutech Mediworld. The patients were diagnosed with $\mathrm{CP}$ elsewhere and referred to us were included in the study. We have previously published the data of these patients with CP assessed using GMFCS scoring [16, 17].

The hESCs were derived from a single, spare, expendable, pre-implantation stage fertilized ovum taken during natural in-vitro fertilization (IVF) process with due consent of the donor. The cells were cultured and maintained as per our in-house patented technology (United States Granted Patent No US $8592,208,52)$ in a good manufacturing practice (GMP), good laboratory practice (GLP) and good 
tissue practice (GTP) compliant certified laboratory $[18,19]$. The safety and efficacy of the cell line has earlier been established. We have used these cell lines to treat over 1300 patients with diverse ailments [19].

\section{Study Design}

The detailed study design is elaborated elsewhere [16]. The patients with CP were initially tested for hypersensitivity reactions with hESC $(0.25 \mathrm{~mL}$ hESC injected subcutaneously). Afterwards, they entered the treatment phase which lasted for 8 weeks, where $0.25 \mathrm{~mL}$ ( $\leq 4$ million cells) hESCs were administered through intramuscular (IM) route once daily and $1 \mathrm{~mL}$ of hESC ( $\leq 16$ million cells) was administered twice every 7 days through intravenous (IV) route. In addition, each patient had received a dose of hESCs by caudal route which could be repeated every 5-14 days.

The efficacy of hESC therapy was evaluated based on the Gross Motor Function Classification System - Expanded and Revised (GMFCS - E \& R) score. Single-photon emission computed tomography

Table 1. GMFCS - E \& R score for Evaluating Epilepsy and Speech Outcomes for CP Patients.

\begin{tabular}{|l|c|c|}
\hline Parameter & Description & Score \\
\hline \multirow{3}{*}{ Epilepsy } & Less frequent than in 4 & 1 \\
\hline 1-2 times/week or occasionally & 2 \\
\hline \multirow{4}{*}{ Speech } & $1-2$ times/alternative day & 3 \\
\hline & $1-2$ times/day & 4 \\
\hline Multiple times/day & 5 \\
\hline Slurred, able to form many words & 2 \\
\hline Able to form few words & 3 \\
\hline Able to form single word & 4 \\
\hline Completely non verbal & 5 \\
\hline Not afflicted in CP & NAA \\
\hline
\end{tabular}

(SPECT) scan of the patients was performed before and after the therapy $[16,20]$.

\section{Epilepsy and Speech levels of scoring}

The epilepsy and speech outcomes were evaluated on Levels 5 (Bad) - 1 (Good). Table 1 shows the different levels of the scale that we used to score epilepsy and speech disorders in these patients.

\section{Results}

\section{Patients}

Of the 101 patients included in the study, 29 (28.71\%) were women and 72 (71.28\%) were men. The age of the patients ranged from 30 days to 18 years. Of 101 patients, 59 (58.41\%) had epileptic problems and 93 (92.07\%) were suffering from speech disorders. The demographic characteristics of all the patients included in this study are summarized in Table 2.

Table 2. Demographic Characteristics of $101 \mathrm{~Pa}$ tients with Severe CP who were Treated with hESCS.

\begin{tabular}{|c|c|c|}
\hline \multicolumn{2}{|c|}{ Parameters } & Values \\
\hline \multicolumn{2}{|l|}{ Age } & 30 days-18 yr \\
\hline \multirow{2}{*}{ Gender } & Male (n\%) & 71.28 \\
\hline & Female $(n \%)$ & 28.71 \\
\hline \multicolumn{2}{|c|}{ Duration of treatment ( $\mathrm{T} 1$ ) } & 56 days (8 weeks) \\
\hline \multicolumn{2}{|c|}{$\begin{array}{l}\text { Number of epileptic } \\
\text { patients }(\mathrm{N})\end{array}$} & 59 \\
\hline \multicolumn{2}{|c|}{$\begin{array}{l}\text { Number of patients with } \\
\text { speech disorder }(\mathrm{N})\end{array}$} & 93 \\
\hline \multicolumn{2}{|l|}{ Dose } & $\begin{array}{c}0.23 \mathrm{~mL}(<4 \text { million cells) } \\
\text { hESCs (IM route) once daily } \\
\text { and } 1 \mathrm{~mL} \text { of hESC ( }<16 \text { million } \\
\text { cells) twice } \\
\text { Every } 7 \text { days through IV route. }\end{array}$ \\
\hline
\end{tabular}




\section{Efficacy Evaluation}

The efficacy studies for epilepsy and speech outcomes were compared at baseline (before treatment) and after treatment using GMFCS- E\& R scores.

\section{Changes in Improvement for Epilepsy Patients- Before and after the end of therapy}

Figure 1 shows the GMFCS scores for epileptic patients

Overall, of the 59 epileptic patients who received hESC therapy, a considerable improvement was observed in all the patients assessed. At baseline, there were 27 (45.8\%) patients at level 5, 13 (22\%) patients were at level 4 , at level 3 and 2 , there were $11(18.6 \%)$ and $5(8.5 \%)$ patients, respectively. There was a single patient $(1.7 \%)$ at level 1.

At the end of the therapy, there was a significant improvement among all the patients treated. None of the patients were at level 5 and 4 . There were 8 (13.6\%) patients at level 3 and 31 (52.5\%) patients at level 2. Overall, 18 (30.5\%) patients showed complete improvement and reached the stage of normalcy at level 1.

\section{Changes in Improvement for Patients with Speech disorders. Before and after the end of therapy}

Figure 2 shows the GMFCS scores for patients with speech disorders

Of 93 patients included for speech disorders, at baseline, $40(42 \%)$ patients were at level 5 who were completely speechless. At level 4 , there were $20(21.5 \%)$ patients who could form a single word. There were $15(16.1 \%)$ and 10 (10.8\%) patients at level 3 and 2, respectively. After hESC therapy, none of the patient remained non-verbal. There was reported remarkable improvement in $27(29 \%)$ patients, who scored level 1. A total of $48(51.6 \%)$ patients were at level 2, there were $10(10.8 \%)$ patients at level 3 and none of the patients were at level 4 and 5 . At the end of study, none of the patients remained babbling and non-verbal.

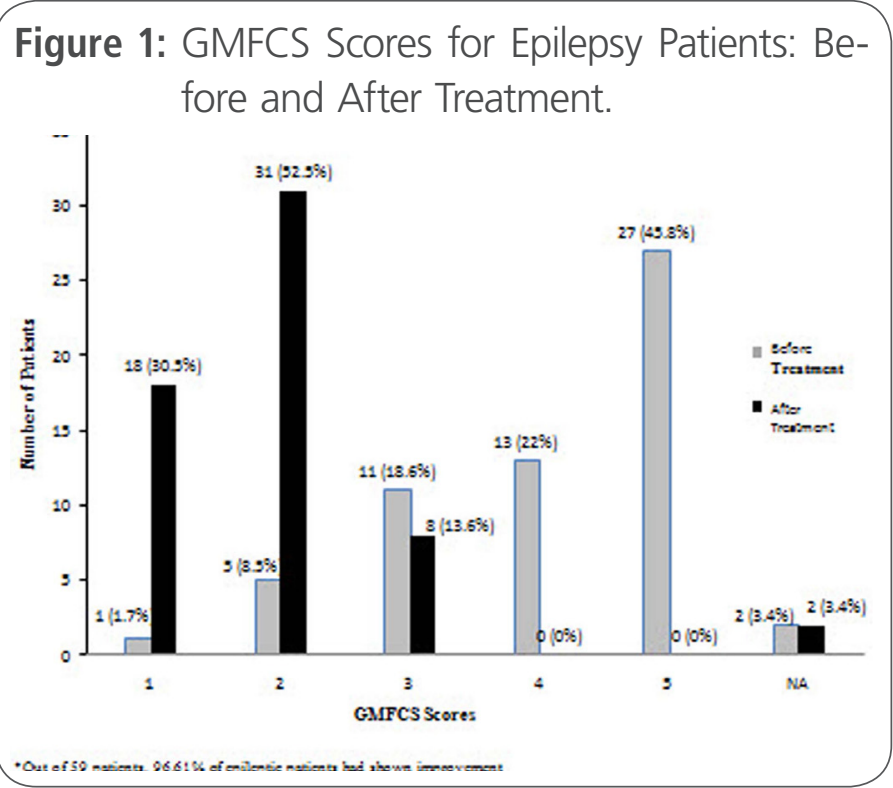

Figure 2: GMFCS Scores for Patients with Speech Disorders: Before and After Treatment.

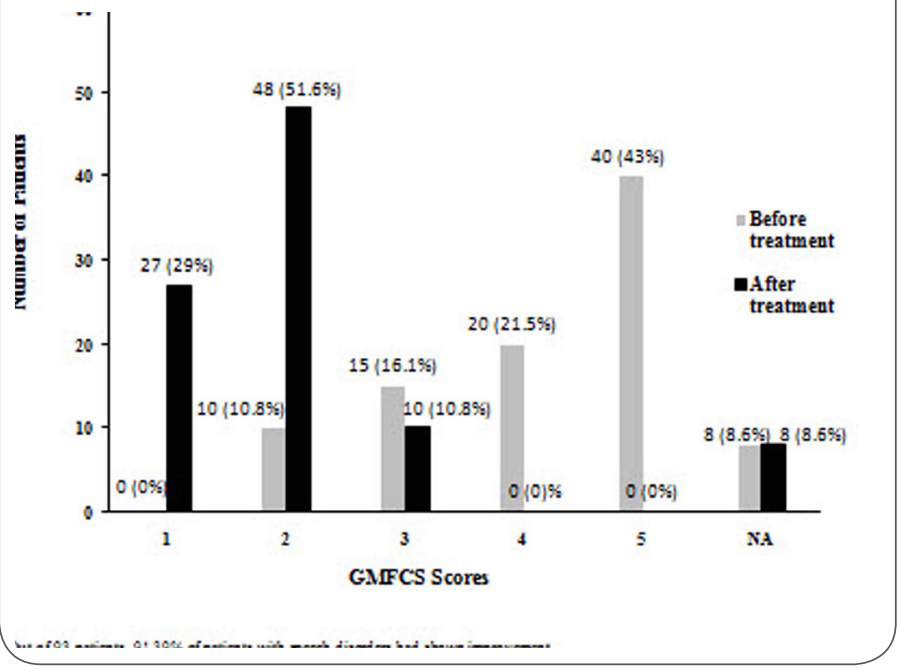

\section{SPECT scan}

At the beginning and at the end of the study, patients underwent SPECT scan. Hypoperfusion was either observed in the left and right part of the brain. The SPECT scan of one of the patient has been illustrated in Figure 3 (a) and (b). 
Figure 3: SPECT scan of a Cerebral Palsy Patient (a) Before the treatment (b) After the treatment.

(a)

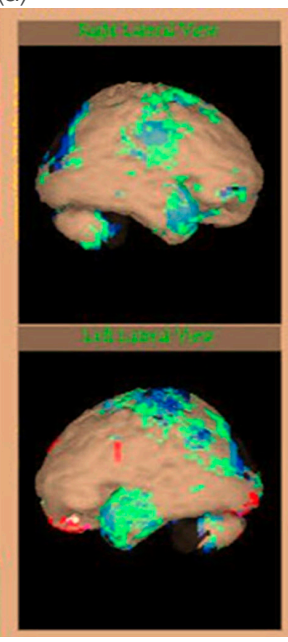

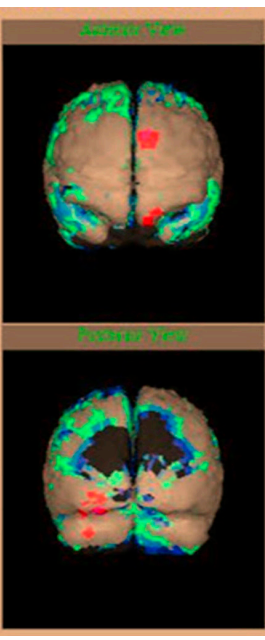

Grey - normal; red, pink and white - (b)
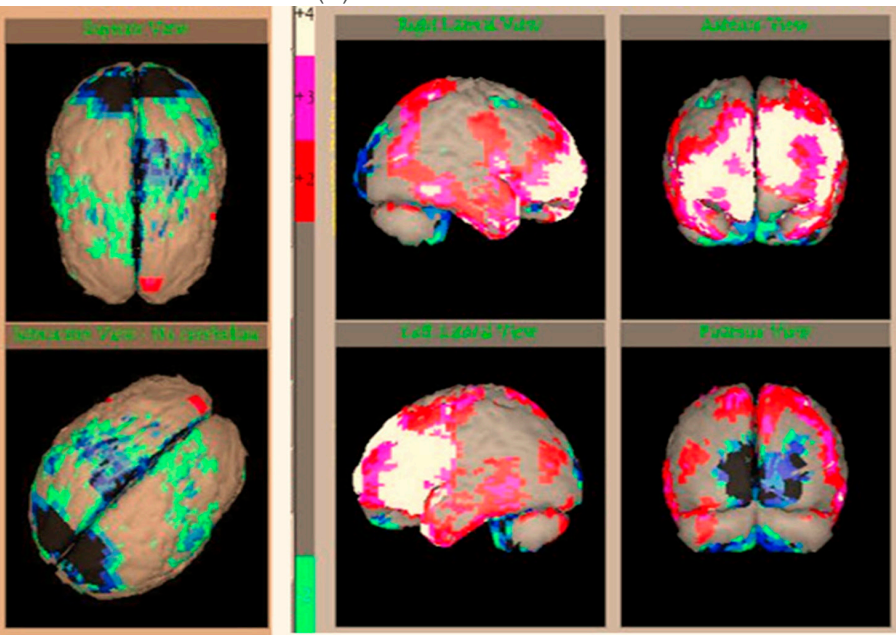

- above normal; green, light/dark blue, black -hypoperfused

\section{Discussion}

Many confounding factors in CP affect the overall quality of life of an individual; of which epilepsy and language/speech disorders are the most frequent $[8,18,21]$. It has been found that 15-60\% of children with CP are affected with epilepsy [22]. Such patients suffer frequent attacks of epileptic seizures like generalized tonic clonic, myoclonic/ atonic, partial seizures and few of them also are victims of other epileptic associated syndromes viz infantile spasms, west and lennox-gastaut syndrome $[23,24]$. Though seizures can be controlled by pharmacotherapy, but epilepsy still remains an area of concern as epilepsy in patients with CP is of severe nature and difficult to control. These attacks sometimes are so scary that the young children get mentally as well as physical harmed $[25,26]$.

In order to control the seizures and spasms, physicians prescribe various antiepileptic drugs (AEDs) to CP patients, but all these medications either have adverse events such as digestive problems, breathing difficulties, skin conditions, and behavioral or learning issues, so patients don't benefit much with such treatments $[1,25,27]$ or patients have poor response to AEDs. Also, the risk of seizure relapse after AED discontinuation worsens the patient's condition $[3,28]$. Bruck et al showed that most of the CP patients who have epilepsy disorders are often associated with speech disorders too. The severity of speech may have different levels; patients are either completely non verbal or are mono-syllable (not able to form single word); disyllable (not able to form many words) or cannot form sentences. As per the study conducted by Parkes et al and Bax et al (European study); approximately 35\% of young people with CP have dysarthria and $60 \%$ of children have some kind of communication problems, respectively $[6,29,30]$. There are no such treatments available which can improve speech in CP patients. Though rehabilitation services for speech and language therapy (SLT) are available to improve communication skills, but there are no studies available to support the evidence for the maintenance of these skills in future. SLT also depends on the effectiveness of training provided which may vary with different service providers [30, 31].

Data reported from several retrospective studies and systematic reviews shows that the conventional treatments used to treat CP and its associated symptoms such as botox, baclofen to control muscle spasms and seizures, glycopyrrolate to control drooling and pamidronate to control osteoporosis are 
not the effective treatments to cure it permanently [32-34]. These treatments have limitations to treat CP at GMFCS levels IV and V only [35].

Unlike other cells of the body, the brain cells have a very limited capacity for self-repair as mature and old neurons cannot regenerate. Epilepsy in CP is often caused either due to degeneration of neurons or deficiency and dysfunctioning of neurotransmitters like gamma amino butyric acid (GABA). Thus, it can be controlled by two mechanisms, either by the replacement of damaged or lost neurons or by substitution of physiological mediator [36]. Studies by Naegele et al in animal models have shown that transplanted embryonic stem cells in the developing brain of mouse models of epilepsy can generate dopaminergic, motor, and GABAergic neuron which can control seizures, thus helps in improving the GABAergic function of neurons [37]. hESCs have the capability to restore damaged neurons and replace them with fresh neurons. These cell lines not only raise the seizure threshold but also suppress recurrent spontaneous seizures [38].

In the present study, hESCs after being injected in CP patients, might have migrated to the appropriate sites of injured brain; differentiated into neuronal and glial lineages and integrated and made connections with the host neurons. The transplanted cell lines generated new neurons and received excitatory input from host neurons which in turn generated inhibitory responses like inhibitory neurotransmitter GABA and astrocytes which secretes anticonvulsant factors such as the glial cell-line derived neurotrophic factor (GDNF). It helps to reverse the electrical hyperactivity in the most hyperexcitable parts of brain i.e. hippocampus and substantia nigra that results in seizures [39-42].

Various preclinical and clinical studies are ongoing with different kind of stem cells like mesenchymal stem cells, pluripotent stem cells and bone marrow cells etc to treat $C P$ and its associated comorbidities $[27,43]$. Being pluripotent and autologus in nature, stem cells might have a huge potential in treating these disorders. Animal studies have shown promising results; wherein stem cells are able to reduce neuron damage and return motor function, improves cognitive function after any kind of brain injury $[44,45]$. Many preclinical studies have demonstrated that stem cell therapy can be effective in treating temporal lobe epilepsy (TLE) [46, 47]. Even FDA has approved a couple of clinical trials based on promising results; two US clinical trials and few other foreign trials using stem cells are ongoing to establish their safety and efficacy for CP [48-50]. Though the ethical concerns and safety issues for using stem cells in humans is still a controversial topic in scientific research; but the scientific community is constantly evolving to tackle this appropriately [45].

hESC therapy developed at our facility is patented, xeno-free and have proven safety and efficacy in various neurological disorders [18]. The safety and effectiveness of hESC treatment for CP patients has also been proven with other radiological investigations such as SPECT in our previous findings [20]. The patients who were admitted at our facility did not benefit from the traditional therapies with which they had been treated earlier. hESC treatment for all these patients had shown significant improvement; the patients who had complaints of multiple episodes of epilepsy in a day were reduced in majority after hESC therapy. Very few studies have been reported to treat speech disorders using hESC, the CP patients who were treated for speech disorders with our prepared cell lines had shown noticeable improvement; the patients who were unable to speak even a single word before receiving hESC therapy became completely verbal after getting this novel treatment.

\section{Conclusion}

hESCs represent a promising source of generating neurons to treat neurological conditions like epilepsy and other motor disturbances like deformed 
speech associated with CP. Unlike other conventional treatments discussed, the hESC therapy is able to measure all GMFCS levels for CP and its co-morbidities. The scores show that the hESC treatment has improved the overall well being of the $101 \mathrm{CP}$ patients with a single session of therapy provided. However, future clinical studies are needed to further support our findings.

\section{Acknowledgements}

The author acknowledges all the doctors, staff and patients of the NutechMediworld. The author also acknowledges Knowledge Isotopes Pvt. Ltd. (http:// www.knowledgeisotopes.com) for the writing support.

\section{Funding}

None

\section{Conflicts of interest}

No competing interests exist.

\section{Abbreviations}

CP: Cerebral Palsy

ADDM: Autism and Developmental Disabilities Monitoring

UCBSCs: Umbilical cord blood stem cells

iPSCs: Induced pluripotent stem cells

hESC: Human embryonic stem cell

IEC: Independent Ethics Committee

IVF: In-vitro fertilization

GMP: Good manufacturing practice

GLP: Good laboratory practice

GTP: Good tissue practice

IM: Intramuscular

IV: Intravenous

GMFCS-E \& R: Gross Motor Function Classification System-Expanded and Revised

SPECT: Single-photon emission computed tomography
AEDs: Antiepileptic drugs

SLT: Speech and language therapy

GABA: Gamma amino butyric acid

GDNF: Glial cell-line derived neurotrophic factor

TLE: Temporal lobe epilepsy

\section{References}

1. Wallace SJ. Epilepsy in cerebral palsy. Developmental medicine and child neurology. 2001; 43(10): 713-7.

2. Christensen D, Van Naarden Braun K, Doernberg NS, Maenner $\mathrm{MJ}$, Arneson CL, Durkin MS, et al. Prevalence of cerebral palsy, co-occurring autism spectrum disorders, and motor functioning - Autism and Developmental Disabilities Monitoring Network, USA, 2008. Developmental medicine and child neurology. 2014; 56(1): 59-65.

3. Aksu F. Nature and prognosis of seizures in patients with cerebral palsy. Developmental medicine and child neurology. 1990; 32(8): 661-8.

4. Longo M, Hankins GD. Defining cerebral palsy: pathogenesis, pathophysiology and new intervention. Minerva ginecologica. 2009; 61(5): 421-9.

5. Grether JK, Nelson KB. Maternal infection and cerebral palsy in infants of normal birth weight. Jama. 1997; 278(3): 207-11.

6. Bax M, Tydeman C, Flodmark O. Clinical and MRI correlates of cerebral palsy: the European Cerebral Palsy Study. Jama. 2006; 296(13): 1602-8.

7. Palisano R, Rosenbaum P, Walter S, Russell D, Wood E, Galuppi B. Development and reliability of a system to classify gross motor function in children with cerebral palsy. Developmental medicine and child neurology. 1997; 39(4): 214-23.

8. Kakooza-Mwesige A, Forssberg $H$, Eliasson AC, Tumwine JK. Cerebral palsy in children in Kampala, Uganda: clinical subtypes, motor function and co-morbidities. BMC research notes. 2015; 8: 166.

9. Ansel BM, Kent RD. Acoustic-phonetic contrasts and intelligibility in the dysarthria associated with mixed cerebral palsy. Journal of speech and hearing research. 1992; 35(2): 296-308.

10. Gabis LV, Tsubary NM, Leon O, Ashkenasi A, Shefer S. Assessment of abilities and comorbidities in children with cerebral palsy. Journal of child neurology. 2015.

11. Ashwal S, Russman BS, Blasco PA, Miller G, Sandler A, Shevell $M$, et al. Practice parameter: diagnostic assessment of the child with cerebral palsy: report of the Quality Standards Subcommittee of the American Academy of Neurology and the Practice Committee of the Child Neurology Society. Neurology. 2004; 62(6): 851-63. 
12. Franki I, Desloovere K, De Cat J, Tijhuis W, Molenaers G, Feys H, et al. An evaluator-blinded randomized controlled trial studying therapy effects and prognostic factors for a general and an individually defined physical therapy program in ambulant children with bilateral spastic cerebral palsy. European journal of physical and rehabilitation medicine. 2015.

13. Erices A, Conget $P$, Minguell JJ. Mesenchymal progenitor cells in human umbilical cord blood. British journal of haematology. 2000; 109(1): 235-42

14. Nieda M, Nicol A, Denning-Kendall P, Sweetenham J, Bradley B, Hows J. Endothelial cell precursors are normal components of human umbilical cord blood. British journal of haematology. 1997; 98(3): 775-7.

15. Kang M, Min K, Jang J, Kim SC, Kang MS, Jang SJ, et al. Involvement of immune responses in the efficacy of cord blood cell therapy for cerebral palsy. Stem cells and development. 2015; 24(19): 2259-68.

16. Shroff G, Gupta A, Barthakur JK. Therapeutic potential of human embryonic stem cell transplantation in patients with cerebral palsy. Journal of translational medicine. 2014; 12: 318.

17. Shroff G, Barthakur JK, Mohan P, Mahajan H. Single Photon Emission Computed Tomography Scan as a Diagnostic Tool in Children with Cerebral Palsy Treated with Human Embryonic Stem Cells. J Nucl Med Radiat Ther 2015; 6(3).

18. Shroff G. Establishment and characterization of a neuronal cell line derived from a 2-cell stage human embryo: clinically tested cell-based therapy for neurological disorders. International Journal of Recent Scientific Research. 2015; 6(4): 3730-8.

19. Shroff G, Barthakur JK. Safety of human embryonic stem cells in patients with terminal/incurable conditions- a retrospective analysis. Annals of neurosciences. 2015; 22(3): 132-8.

20. Shroff G, Barthakur JK, Mohan P, Mahajan H. Single Photon Emission Computed Tomography Scan as a Diagnostic Tool in Children with Cerebral Palsy Treated with Human Embryonic Stem Cells. J Nucl Med Radiat Ther 2015; 6: 223

21. Barbro Lindquist EF, Eva-Karin Persson, Paul Uvebrant. Quality of life in adults treated in infancy for hydrocephalus. Childs Nerv Syst. 2014; 30(8): 1413-18.

22. Gururaj AK, Sztriha L, Bener A, Dawodu A, Eapen V. Epilepsy in children with cerebral palsy. Seizure. 2003; 12(2): 110-4.

23. Knezevic-Pogancev M. Cerebral palsy and epilepsy. Medicinski pregled. 2010; 63(7-8): 527-30.

24. Singhi $P$, Jagirdar $S$, Khandelwal N, Malhi P. Epilepsy in children with cerebral palsy. Journal of child neurology. 2003; 18(3): 1749.

25. The ultimate resource for everything cerebral pasy [Internet]. [cited 2015 Aug 24]. Available from: http://cerebralpalsy.org/ information/seizure-control/

26.Isac Bruck SAA, Adriane Spessatto, Ricardo Schmitt de Bem, Romeu Hausberger, Carlos Gustavo Pacheco. Epilepsy in children with cerebral palsy. Arq Neuro-Psiquiatr. 2015; 59(1).
27. Miao X, Wu X, Shi W. Umbilical cord mesenchymal stem cells in neurological disorders: A clinical study. Indian journal of biochemistry \& biophysics. 2015; 52(2): 140-6.

28. Aneja S, Ahuja B, Taluja V, Bhatia VK. Epilepsy in children with cerebral palsy. Indian journal of pediatrics. 2001; 68(2): 111-5.

29. Parkes J, Hill N, Platt MJ, Donnelly C. Oromotor dysfunction and communication impairments in children with cerebral palsy: a register study. Developmental medicine and child neurology. 2010; 52(12): 1113-9.

30. Watson RM, Pennington L. Assessment and management of the communication difficulties of children with cerebral palsy: a UK survey of SLT practice. International journal of language \& communication disorders / Royal College of Speech \& Language Therapists. 2015; 50(2): 241-59.

31. Pennington L, Goldbart J, Marshall J. Speech and language therapy to improve the communication skills of children with cerebral palsy. The Cochrane database of systematic reviews. 2004(2): CD003466.

32. Copeland L, Edwards P, Thorley M, Donaghey S, Gascoigne-Pees $\mathrm{L}$, Kentish $\mathrm{M}$, et al. Botulinum toxin A for nonambulatory children with cerebral palsy: a double blind randomized controlled trial. The Journal of pediatrics. 2014; 165(1): 140-6 e4.

33. Dai Al, Aksoy SN, Demiryurek AT. Comparison of Efficacy and Side Effects of Oral Baclofen Versus Tizanidine Therapy with Adjuvant Botulinum Toxin Type A in Children With Cerebral Palsy and Spastic Equinus Foot Deformity. Journal of child neurology. 2015.

34. Naidu K, Smith K, Sheedy M, Adair B, Yu X, Graham HK. Systemic adverse events following botulinum toxin $A$ therapy in children with cerebral palsy. Developmental medicine and child neurology. 2010; 52(2): 139-44.

35. Mesterman R, Gorter JW, Harvey A, Lockhart J, McEwen-Hill J, Margallo $K$, et al. Botulinum toxin type $A$ in children and adolescents with severe cerebral palsy: a retrospective chart review. Journal of child neurology. 2014; 29(2): 210-3.

36. Goodarzi P, Aghayan HR, Soleimani M, Norouzi-Javidan A, Mohamadi-Jahani F, Jahangiri $S$, et al. Stem cell therapy for treatment of epilepsy. Acta medica Iranica. 2014; 52(9): 651-5.

37. Naegele JR, Vemuri MC, Studer L. Embryonic Stem Cell Therapy for Intractable Epilepsy. In: Noebels JL, Avoli M, Rogawski MA, Olsen RW, Delgado-Escueta AV, editors. Jasper's Basic Mechanisms of the Epilepsies. 4th ed. Bethesda (MD)2012.

38. DeRosa BA, Belle KC, Thomas BJ, Cukier HN, Pericak-Vance MA, Vance JM, et al. hVGAT-mCherry: A novel molecular tool for analysis of GABAergic neurons derived from human pluripotent stem cells. Molecular and cellular neurosciences. 2015; 68: 24457. 
39. Human stem cell-derived neuron transplants reduce seizures in mice [Internet]. Available at: Harvard Stem cell Institute; 2014 [cited 2014]. Available from: http://hsci.harvard.edu/news/ human-stem-cell-derived-neuron-transplants-reduce-seizuresmice

40. Kriegstein A, Alvarez-Buylla A. The glial nature of embryonic and adult neural stem cells. Annual review of neuroscience. 2009; 32: 149-84.

41. Goldberg EM, Coulter DA. Seizing the opportunity: stem cells take on epilepsy. Cell stem cell. 2014; 15(5): 527-8.

42. Janice R. Naegele XM. Gene and stem cell therapies for treating epilepsy 2010

43. Fan $\mathrm{HC}$, Ho LI, Chi CS, Cheng SN, Juan CJ, Chiang KL, et al. Current proceedings of cerebral palsy. Cell transplantation. 2015; 24(3): 471-85

44. Carroll JE, Mays RW. Update on stem cell therapy for cerebral palsy. Expert opinion on biological therapy. 2011; 11(4): 463-71.

45. Crystal Ruff JW, Michael G. Fehlings, Krembil. Current status of stem cells treatments for cerebral palsy; A guide for patients, families and caregivers. NeuroDevNet. 2011.

46. Hunt RF, Girskis KM, Rubenstein JL, Alvarez-Buylla A, Baraban SC. GABA progenitors grafted into the adult epileptic brain control seizures and abnormal behavior. Nature neuroscience. 2013; 16(6): 692-7.

47. Shashank Chandanala HPY, Chiatra Venugopal, Anandh Dhanushkodi. Stem Cells Based Therapy for Temporal Lobe Epilepsy Journal of Clinical and Biomedical Sciences. 2014; 4(2): 267-71.

48. Safety and Effectiveness of Cord Blood Stem Cell Infusion for the Treatment of Cerebral Palsy in Children [Internet]. 2015 [cited 27 Aug 2015]. Available from: http://clinicaltrials.gov/ct2/ show/NCT01072370?term=stem+cells+and+cerebral+palsy\&ra nk=5\&submit fld opt=

49. Safety and Effectiveness of Banked Cord Blood or Bone Morrow Stem Cells in Children With Cerebral Palsy (CP). (ACT for CP). USA 2015.

50. Cell Therapy for Cerebral Palsy [Internet]. 2014 [cited 2015 Aug 27]. Available from: http://clinicaltrials.gov/ct2/show/NCT022 41395?term=stem+cells+and+cerebral+palsy\&rank=10\&subm it fld opt=
Publish in International Archives of Medicine

International Archives of Medicine is an open access journal publishing articles encompassing all aspects of medical science and clinical practice. IAM is considered a megajournal with independent sections on all areas of medicine. IAM is a really international journal with authors and board members from all around the world. The journal is widely indexed and classified Q1 in category Medicine. 